Journal of Environmental Engineering and Science

Volume 10 Issue JS2

Effect of hydrogen peroxide on radiofrequency-oxidation of dairy manure Srinivasan, Young, Liao and Lo
Journal of Environmental Engineering and Science, 2015, 10(2), 40-45 http://dx.doi.org/10.1680/jees.15.00003 Paper 15.00003

Received 25/02/2015; accepted 29/06/2015

Published online 23/07/2015

Keywords: research \& development/thermal effects/waste management \& disposal

ICE Publishing: All rights reserved

\title{
Effect of hydrogen peroxide on radiofrequency-oxidation of dairy manure
}

Asha Srinivasan $\mathrm{PhD}$

Postdoctoral Fellow, Department of Civil Engineering, University of British Columbia, Vancouver, Canada

Chris Young BASC

Graduate Student, Department of Civil Engineering, University of British Columbia, Vancouver, Canada
Ping Huang Liao PhD

Research Associate, Department of Civil Engineering, University of British Columbia, Vancouver, Canada

Kwang Victor Lo PhD

Professor, Department of Civil Engineering, University of British Columbia, Vancouver, Canada

\begin{abstract}
A novel technology involving a combination of radiofrequency (RF) heating and hydrogen peroxide $\left(\mathrm{H}_{2} \mathrm{O}_{2}\right)$ addition was used to treat dairy manure as a part of a manure management and resource recovery scheme; the process was to release nutrients and to disintegrate dairy manure for subsequent struvite crystallisation process and/or anaerobic digestion. The factors affecting the process, namely, $\mathrm{H}_{2} \mathrm{O}_{2}$ dosage, heating time and radiofrequency temperature, were studied using a surface response design methodology. The results indicated that solids disintegration efficiency in terms of soluble chemical oxidation demand concentration in the treated solution was in a range of 15-18\% of total chemical oxygen demand. Very high volatile fatty acid concentrations were also produced. Orthophosphate (ortho-P) concentrations were in the range of $\mathbf{3 6 - 5 2 \%}$ of total phosphorus in the treated solution. The optimal operating conditions for both solids disintegration and ortho-P release were predicted to be RF temperature of $83^{\circ} \mathrm{C}$, holding time of $55-60$ min and $\mathrm{H}_{2} \mathrm{O}_{2}$ dose of $1.7-1.8 \%$.
\end{abstract}

\section{Introduction}

Dielectric heating is generated by the interaction of dielectric materials with electromagnetic radiation: radiofrequency (RF) heating is operated at frequencies $13 \cdot 56,27 \cdot 12$ and $40 \cdot 68 \mathrm{MHz}$ and microwave (MW) heating is carried out at 915 and $2450 \mathrm{MHz}$ in North America (Laughton and Warne, 2003). Dielectric heating provides uniform and faster heating rates than conventional heating processes. The longer wavelength of RF allows for a greater depth of penetration, compared to MW. RF technology has applications in drying of food products in the food processing industry, soil remediation, off-gas and natural gas treatments and disinfection of wastewaters (Lagunas-Solar et al., 2005; Ramaswamy and Tang, 2008).

The RF heating process was utilised as a pretreatment process for nutrients release and solids disintegration from dairy manure; the purpose of this process was to increase yields of phosphorus recovery and/or bioenergy production in the subsequent processes. The treatment efficiency of the RF process was found to be comparable to that of the MW process (Nkansah-Boadu et al., 2015). The RF-oxidation (RF/hydrogen peroxide $\left.\left(\mathrm{H}_{2} \mathrm{O}_{2}\right)\right)$ process, which uses a combination of RF heating with $\mathrm{H}_{2} \mathrm{O}_{2}$, had higher treatment efficiency than $\mathrm{RF}$ heating alone. The factors affecting treatment efficiency of the $\mathrm{RF} / \mathrm{H}_{2} \mathrm{O}_{2}$ process are $\mathrm{H}_{2} \mathrm{O}_{2}$ dosage, power intensity, temperature and reaction time. In the previous $\mathrm{RF} / \mathrm{H}_{2} \mathrm{O}_{2}$ studies on the separated solids fraction from dairy manure, phosphorous release was $29-76 \%$ of total phosphate (TP), whereas soluble chemical oxygen demand (SCOD) was in a range of $6-30 \%$ of total chemical oxygen demand (TCOD) (NkansahBoadu et al., 2015). Very low yields of solids disintegration were due to constituents of dairy manure itself, which were very difficult to hydrolyse, and low dosages of $\mathrm{H}_{2} \mathrm{O}_{2}\left(0 \cdot 1,0 \cdot 2\right.$ and $0 \cdot 3 \% \mathrm{H}_{2} \mathrm{O}_{2}$ per \%total solids (TS)) were used. Dairy manure contains fats, proteins, lignin, carbohydrates and inorganic residue, as well as nutrients and metals. The solids fraction of dairy manure after liquid-solids separation resulted in higher lingo-cellulosic and phosphorus content than that of unseparated manure, making the separated fractions a better substrate for nutrient and energy recovery (Barnett, 1994; Hjorth et al., 2010; Rico et al., 2007). Nkansah-Boadu et al. (2015) concluded that in order to obtain the most nutrients and soluble materials from separated solids manure, lower power intensity and holding times between 20 and $60 \mathrm{~min}$ should be used, and higher $\mathrm{H}_{2} \mathrm{O}_{2}$ dosages are needed.

This study was designed to use higher $\mathrm{H}_{2} \mathrm{O}_{2}$ dosage $(0 \cdot 3-0 \cdot 5 \%$ $\mathrm{H}_{2} \mathrm{O}_{2}$ per \%TS ) and lower holding time (20-60 min). The objective was to explore optimal operating conditions for achieving a high degree of solids disintegration and nutrient solubilisation from dairy manure.

\section{Materials and methods}

Apparatus

A $6 \mathrm{~kW}$ radiofrequency oven (RF) was used in this study. The $\mathrm{RF}$ electrodes were housed in an aluminium box suspended 
Journal of Environmental Engineering and Science

Volume 10 Issue JS2
Effect of hydrogen peroxide on

radiofrequency-oxidation of dairy manure

Srinivasan, Young, Liao and Lo on polypropylene insulators. A transmission line connected the generator output to the oven electrode. The system had a capacity of accommodating up to $9 \mathrm{~L}$ of sample in a single run at an operating temperature of up to $95^{\circ} \mathrm{C}$. Commercially available microwave-safe plastic containers of $1.5 \mathrm{~L}$ total capacity were used as reaction vessels, with aluminium plates moulded to their bottom surface. The vessels were covered with an aluminium lid that was attached to another aluminium base plate with Teflon spacers in between. The temperature was measured using a Neoptix fibre optic probe inserted into the container through a hole in the lid. The aluminium lid can be removed from the container, without removing the Teflon spacers and base plate, when experiments are not performed.

\section{Substrate}

Separated dairy manure was obtained from the Dairy Education \& Research Centre, University of British Columbia in Agassiz, British Columbia, Canada, and it was stored in the Department of Civil Engineering Laboratory at $4^{\circ} \mathrm{C}$. Separated dairy manure contained large amounts of sand, bedding material, as well as undigested lingocellulosic materials. For the separated dairy manure, distilled water was added to the samples and subsequently decanted to remove the sand. The resulting separated dairy manure had $5 \cdot 5 \%$ TS.

\section{Experimental design}

The manure samples, acidified using sulphuric acid to $\mathrm{pH} 4 \cdot 0$, were subjected to the RF heating process. The study was carried out in three $1.5 \mathrm{~L}$ vessels, and a sample volume of $600 \mathrm{~mL}$ in each vessel was used. Using a statistical program, MINITAB, version
$16 \cdot 0$, an experimental design consisting of 15 trials was selected (Minitab, 2007). The Box-Behnken design for response surface plots was chosen for the experiments. The three factor levels chosen were temperature of $75^{\circ} \mathrm{C}, 85^{\circ} \mathrm{C}$ and $95^{\circ} \mathrm{C}$, holding time of 20,40 and $60 \mathrm{~min}$ and $\mathrm{H}_{2} \mathrm{O}_{2}$ dosage of $1.5,2 \cdot 0$ and $2.5 \%$ (v/v) (Table 1). $\mathrm{H}_{2} \mathrm{O}_{2}$ dosages were equivalent to $0 \cdot 1,0 \cdot 3$ and $0.5 \% \mathrm{H}_{2} \mathrm{O}_{2}$ per $\% \mathrm{TS}$. Initially, the RF power was set at $35 \%$ (approximately $1.2 \mathrm{~kW} / \mathrm{L}$ manure treated) until the manure samples reached the desired temperature, after which they were held at that temperature for the desired holding time.

\section{Chemical and statistical analysis}

The initial and treated dairy manure samples were centrifuged at $4500 \mathrm{rpm}$ for $10 \mathrm{~min}$ first, and then their supernatants were extracted for analysing SCOD, orthophosphate (ortho-P), ammonia, volatile fatty acids (VFA) and metals in the soluble portion. All of the chemical analyses were carried out following the procedures outlined in Standard Methods (APHA, 1998). For ortho-P analysis, the initial dairy manure sample was determined at $0 \cdot 5 \%$ TS to ensure correct measurement (Wolf et al., 2005). Treated and initial dairy manure were also analysed for TS, TCOD, TP and total Kjeldahl nitrogen (TKN). Ortho-P, ammonia, TP and TKN were determined by a flow injection system (Lachat Quik-Chem 8000 Automatic Ion Analyzer, Lachat Instruments, USA). A HewlettPackard 6890 Series II gas chromatograph, equipped with a flame ionisation detector, was used to measure VFA. Volatile separation was accomplished with an HP free fatty acid phase column. Calcium $(\mathrm{Ca})$ and magnesium $(\mathrm{Mg})$ were determined using a Varian Spectra 220 Fast Sequential Atomic Absorption Spectrometer.

\begin{tabular}{|c|c|c|c|c|c|c|c|c|c|}
\hline Trial & $T:{ }^{\circ} \mathrm{C}$ & $t: \min$ & D: $\%, v / v$ & TS: \% & Ortho-P: mg/L & Ammonia: mg/L & SCOD: $g / L$ & TCOD: $g / L$ & VFA: $g / L$ \\
\hline Raw & & & & $5 \cdot 5 \pm 0 \cdot 3$ & $14 \pm 7$ & $626 \pm 30$ & $7 \cdot 1 \pm 0 \cdot 7$ & $50 \pm 11$ & $0.9 \pm 0$ \\
\hline Acid & & & & $5 \cdot 4 \pm 0 \cdot 3$ & $135 \pm 8$ & $885 \pm 15$ & $8.5 \pm 0.4$ & $54 \pm 4$ & $0.6 \pm 0$ \\
\hline 1 & 95 & 40 & $2 \cdot 5$ & $5 \cdot 3 \pm 0 \cdot 4$ & $93 \pm 8$ & $778 \pm 12$ & $9 \cdot 4 \pm 0.4$ & $52 \pm 6$ & $5 \cdot 5 \pm 0 \cdot 1$ \\
\hline 2 & 85 & 20 & $1 \cdot 5$ & $5 \cdot 3 \pm 0 \cdot 2$ & $117 \pm 13$ & $790 \pm 26$ & $8 \cdot 8 \pm 0 \cdot 3$ & $55 \pm 0 \cdot 4$ & $5 \cdot 3 \pm 0 \cdot 5$ \\
\hline 3 & 95 & 60 & 2 & $5 \cdot 1 \pm 0 \cdot 0$ & $94 \pm 3$ & $832 \pm 25$ & $8.8 \pm 0.5$ & $54 \pm 5$ & $5 \cdot 1 \pm 0 \cdot 3$ \\
\hline 4 & 85 & 20 & $2 \cdot 5$ & $5 \cdot 1 \pm 0 \cdot 3$ & $109 \pm 6$ & $800 \pm 18$ & $8.9 \pm 0.5$ & $47 \pm 15$ & $5 \cdot 1 \pm 0 \cdot 2$ \\
\hline 5 & 85 & 60 & $2 \cdot 5$ & $5 \cdot 5 \pm 0.0$ & $105 \pm 46$ & $835 \pm 33$ & $8 \cdot 3 \pm 0.2$ & $49 \pm 16$ & $5 \cdot 1 \pm 0$ \\
\hline 6 & 85 & 60 & $1 \cdot 5$ & $5 \cdot 8 \pm 0 \cdot 1$ & $100 \pm 6$ & $840 \pm 22$ & $8 \cdot 1 \pm 0 \cdot 3$ & $53 \pm 24$ & $4 \cdot 9 \pm 0 \cdot 1$ \\
\hline 7 & 85 & 40 & 2 & $5 \cdot 5 \pm 0 \cdot 0$ & $100 \pm 4$ & $803 \pm 25$ & $8.4 \pm 0.4$ & $50 \pm 10$ & $5 \cdot 1 \pm 0 \cdot 2$ \\
\hline 8 & 75 & 40 & $1 \cdot 5$ & $5 \cdot 3 \pm 0 \cdot 1$ & $99 \pm 2$ & $838 \pm 33$ & $8.8 \pm 0.1$ & $47 \pm 1$ & $5 \cdot 0 \pm 0.2$ \\
\hline 9 & 75 & 40 & $2 \cdot 5$ & $4 \cdot 7 \pm 0 \cdot 1$ & $111 \pm 4$ & $815 \pm 30$ & $8.4 \pm 0.3$ & $49 \pm 6$ & $4 \cdot 9 \pm 0$ \\
\hline 10 & 85 & 40 & 2 & $5 \cdot 6 \pm 0.2$ & $105 \pm 4$ & $798 \pm 34$ & $8.4 \pm 0.7$ & $55 \pm 3$ & $4 \cdot 6 \pm 0.3$ \\
\hline 11 & 85 & 40 & 2 & $5 \cdot 7 \pm 0 \cdot 0$ & $89 \pm 6$ & $807 \pm 60$ & $8.1 \pm 0.7$ & $53 \pm 1 \cdot 3$ & $4 \cdot 4 \pm 0 \cdot 1$ \\
\hline 12 & 75 & 60 & 2 & $5 \cdot 6 \pm 0.0$ & $95 \pm 3$ & $803 \pm 41$ & $8.7 \pm 0.7$ & $54 \pm 2$ & $4 \cdot 3 \pm 0 \cdot 1$ \\
\hline 13 & 75 & 20 & 2 & $5 \cdot 6 \pm 0.3$ & $104 \pm 6$ & $760 \pm 31$ & $10 \pm 0 \cdot 3$ & $52 \pm 17$ & $4 \cdot 3 \pm 0 \cdot 1$ \\
\hline 14 & 95 & 40 & 1.5 & $6 \cdot 1 \pm 0 \cdot 1$ & $90 \pm 11$ & $830 \pm 13$ & $8 \cdot 8 \pm 1 \cdot 1$ & $50 \pm 0$ & $4 \cdot 4 \pm 0 \cdot 1$ \\
\hline 15 & 95 & 20 & 2 & $5 \cdot 1 \pm 0 \cdot 2$ & $91 \pm 3$ & $815 \pm 18$ & $8 \cdot 3 \pm 0.3$ & $49 \pm 1$ & $4.9 \pm 0.2$ \\
\hline
\end{tabular}

$T$, temperature; $t$ is holding time; and $D$ is $\mathrm{H}_{2} \mathrm{O}_{2}$ dosage.

Table 1. Experimental results 
Journal of Environmental Engineering and Science

Volume 10 Issue JS2
Effect of hydrogen peroxide on

radiofrequency-oxidation of dairy manure

Srinivasan, Young, Liao and Lo

\section{Results and discussion}

Nutrient release

The dairy manure used in this study had ortho-P of $14 \mathrm{mg} / \mathrm{L}$ and $\mathrm{TP}$ of approximately $240 \mathrm{mg} / \mathrm{L}$ (Table 1). At $\mathrm{pH} 4$, the ortho-P concentration increased to $135 \mathrm{mg} / \mathrm{L}$, which represented almost $60 \%$ of TP, an increase of almost nine times from that of the initial manure. For releasing phosphorus from dairy manure, acid addition was essential (Kenge et al., 2009; Lo and Liao, 2011). Dairy manure contains a lot of undigested animal feed such as straw along with organic matter and lipids; phosphorus in dairy manure is constituted in many forms, such as inorganic $\mathrm{P}$, residual $\mathrm{P}$ (nucleic acid-type), acidsoluble organic $\mathrm{P}$ and lipid $\mathrm{P}$. These are neither very soluble nor easily hydrolysed (Barnett, 1994). Therefore, phosphorus in dairy manure could not be solubilised without addition of acid. With $\mathrm{RF} / \mathrm{H}_{2} \mathrm{O}_{2}$ treatment, ortho-P did not increase more than that of acidified manure.

The regression equation obtained from the statistical analysis of ortho-P data is as follows

$$
\begin{aligned}
& \text { Ortho-P }(\mathrm{mg} / \mathrm{L})=98-5 \cdot 2 T-3 \cdot 5 t \\
& +1 \cdot 6 D+2 \cdot 9 T t-2 \cdot 1 T D \\
& \quad+3 \cdot 4 t D-5 \cdot 8 T^{2}+3 \cdot 6 t^{2}+6 \cdot 1 D^{2}
\end{aligned}
$$

where $T$ is temperature in ${ }^{\circ} \mathrm{C}, t$ is holding time in minutes, and $D$ is $\mathrm{H}_{2} \mathrm{O}_{2}$ dosage in $\% \mathrm{v} / \mathrm{v}$. A correlation coefficient of $78 \%$ was observed. The surface response profile of three factors on ortho-P release is shown in Figure 1. Statistical analysis of results from the experiment's matrix revealed that temperature was the most important factor affecting the ortho-P release. The effect of each factor on ortho-P release in ascending order of significance was temperature $>$ holding time $>\mathrm{H}_{2} \mathrm{O}_{2}$ dosage.

Similar studies on microwave-enhanced advanced oxidation process $\left(\mathrm{MW} / \mathrm{H}_{2} \mathrm{O}_{2}-\mathrm{AOP}\right)$ treatment of dairy manure have shown a strong relationship between heating temperature and soluble phosphorus release; an increase of soluble phosphate in the solution was observed as the microwave temperature increased from $60^{\circ} \mathrm{C}$ to $90^{\circ} \mathrm{C}$ for dairy manure (Pan et al., 2006). However, between the range studied $\left(75^{\circ} \mathrm{C}, 85^{\circ} \mathrm{C}\right.$ and $\left.95^{\circ} \mathrm{C}\right)$ in $\mathrm{RF} / \mathrm{H}_{2} \mathrm{O}_{2}$, temperature had a negative effect on ortho-P release, indicating lower RF temperature would result in higher ortho-P release. A maximum ortho-P release of $117 \mathrm{mg} / \mathrm{L}$ was obtained at $85^{\circ} \mathrm{C}, 20 \mathrm{~min}$ holding time and $1.5 \% \mathrm{H}_{2} \mathrm{O}_{2}$ dosage. The samples treated at $95^{\circ} \mathrm{C}$ resulted in some of the trials with low ortho-P content. One possible explanation for this low release could be that at $95^{\circ} \mathrm{C}$, the resulting solution contained more polyphosphates instead of ortho-P; ortho-P to soluble TP ratios of as low as $78 \%$ were observed at $95^{\circ} \mathrm{C}$. The results also indicated that among the three different holding times tested (20, 40 and $60 \mathrm{~min}$ ), 20 min was sufficient to release most of the soluble TP as ortho-P.

It can be seen from the prediction model that the optimal operating condition for ortho-P release was at temperature of $83^{\circ} \mathrm{C}$, holding time
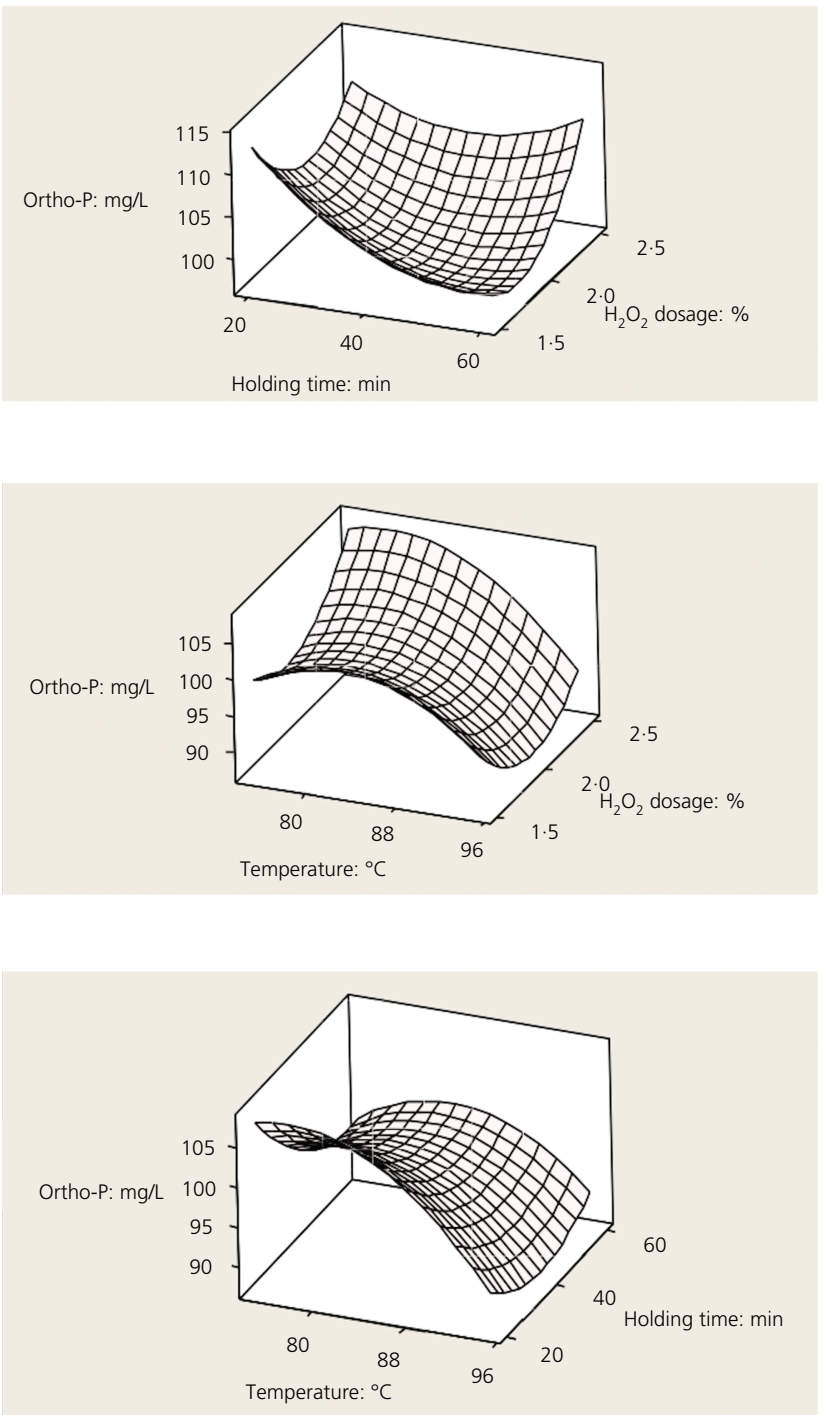

Figure 1. Surface plots for ortho-P release

55 min and $\mathrm{H}_{2} \mathrm{O}_{2}$ dose of $1 \cdot 8 \% . \mathrm{H}_{2} \mathrm{O}_{2}$ dosage had a positive effect on ortho-P release; however, its effect was less compared to RF temperature and reaction time. In the current study, a higher dosage of $\mathrm{H}_{2} \mathrm{O}_{2}(1 \cdot 5 \%, 2 \%$ and $2 \cdot 5 \%)$ was used as opposed to less than $1 \cdot 5 \%$ used in the earlier studies (Nkansah-Boadu et al., 2015). It was evident from the present study's results that with an increased addition of $\mathrm{H}_{2} \mathrm{O}_{2}$, the $\mathrm{RF} / \mathrm{H}_{2} \mathrm{O}_{2}$ could be operated at lower RF temperature or holding time and yet achieve comparable TP to ortho-P conversion.

The ammonia concentrations are presented in Table 1 . Dairy manure had an initial ammonia concentration of $626 \mathrm{mg} / \mathrm{L}$ and a TKN value of $1588 \mathrm{mg} / \mathrm{L}$. As indicated in Table $1,1.5 \%$ of $\mathrm{H}_{2} \mathrm{O}_{2}$ dosage resulted in some of the trials with highest ammonia concentration (trials 6,8 and 14). The lowest ammonia concentration was obtained at $75^{\circ} \mathrm{C}, 2 \% \mathrm{H}_{2} \mathrm{O}_{2}$ and heating time of $20 \mathrm{~min}$ (trial 13). Overall, ammonia did not increase in large quantities after the $\mathrm{RF} / \mathrm{H}_{2} \mathrm{O}_{2}$ 
Journal of Environmental Engineering and

Science

Volume 10 Issue JS2
Effect of hydrogen peroxide on

radiofrequency-oxidation of dairy manure

Srinivasan, Young, Liao and Lo treatment. A possible reason could be that the majority of the nitrogen was degraded into intermediate products, such as amino acids or peptides, while only small amounts of ammonia were formed in the process. Similarly, the ammonia concentration in solution was observed to barely increase after $\mathrm{MW} / \mathrm{H}_{2} \mathrm{O}_{2}$-AOP treatment (Lo and Liao, 2011). There was no significant release of ammonia over the range of $60-80^{\circ} \mathrm{C}$, regardless of the operating conditions (Chan et al., 2010).

The regression equation obtained from the statistical analysis of data is as follows

$$
\begin{aligned}
& \text { Ammonia }(\mathrm{mg} / \mathrm{L})=803+55 T+18 t-8 \cdot 8 D \\
& -6 \cdot 7 T t-7 \cdot 1 T D-3 \cdot 8 t D \\
& \text { 2. } \quad-0.6 T^{2}+0 \cdot 3 t^{2}+13 D^{2}
\end{aligned}
$$

A correlation coefficient of $60 \%$ was observed. Temperature was the most significant factor affecting ammonia release. The combined effects of temperature and time, as well as second order of $\mathrm{H}_{2} \mathrm{O}_{2}$ dosage also resulted in more ammonia being released. The yield of ammonia from this study was comparable to microwave studies to treat dairy manure (Jin et al., 2009; Pan et al., 2006). From the prediction model, the optimal operating condition for releasing ammonia into solution was at a temperature of $107^{\circ} \mathrm{C}$, holding time of $29 \mathrm{~min}$ and $\mathrm{H}_{2} \mathrm{O}_{2}$ dose of $2 \cdot 4 \%$. The critical value of temperature was outside the parameter range studied, implying that more ammonia can be produced with an increase in temperature near $107^{\circ} \mathrm{C}$.

The dairy manure contained $\mathrm{Mg}$ concentration of $279 \pm 17 \mathrm{mg} / \mathrm{L}$ and $\mathrm{Ca}$ of $697 \pm 53 \mathrm{mg} / \mathrm{L}$. It was found that initially, only $189 \pm 19$ and $158 \pm 15 \mathrm{mg} / \mathrm{L}$ of $\mathrm{Mg}$ and $\mathrm{Ca}$, respectively, had solubilised. As noted, most of the potassium contained in the dairy manure was soluble. When the manure was acidified to $\mathrm{pH} 4$, almost all of $\mathrm{Mg}$ and $\mathrm{Ca}$ solubilised. RF heating and $\mathrm{H}_{2} \mathrm{O}_{2}$ had very little effect on the release of $\mathrm{Mg}$ and $\mathrm{Ca}$; the amounts of released metals were dictated by $\mathrm{pH}$.

\section{Solids disintegration}

The soluble COD concentrations are summarised in Table 1. The dairy manure samples had an initial SCOD and TCOD concentration of $7 \cdot 1$ and $50 \mathrm{~g} / \mathrm{L}$, respectively. SCOD in the treated solutions were in a range of $15-19 \%$ of TCOD. High SCOD concentrations were observed in trials 1 and 4 , where $2 \cdot 5 \% \mathrm{H}_{2} \mathrm{O}_{2}$ dosage was used. The TCOD of the $\mathrm{RF} / \mathrm{H}_{2} \mathrm{O}_{2}$ treated dairy manure trials, with $2 \cdot 5 \% \mathrm{H}_{2} \mathrm{O}_{2}$ (trials 1, 4, 5 and 9), were found to decrease; a similar decreasing trend in TS was also observed among these trials. Highest SCOD concentration was observed at $75^{\circ} \mathrm{C}, 20 \mathrm{~min}$ holding time and $2 \%$ $\mathrm{H}_{2} \mathrm{O}_{2}$ dosage. Its concentration increased to $10 \mathrm{~g} / \mathrm{L}$, representing an increase of about $41 \%$. It should be noted that for this treatment trial, the manure was acidified to $\mathrm{pH} 3 \cdot 5$, which was slightly lower than all other trials ( $\mathrm{pH} 4 \cdot 0)$. Settling property of this treatment trial was also observed to be better than other $\mathrm{RF} / \mathrm{H}_{2} \mathrm{O}_{2}$ trials. Similar results were reported in the previous $\mathrm{MW} / \mathrm{H}_{2} \mathrm{O}_{2}$-AOP studies; a higher SCOD in the treated solution, as well as a better settling property, was obtained at a higher $\mathrm{H}_{2} \mathrm{O}_{2}$, a higher microwave temperature and a lower pH (Lo and Liao, 2011; Zhang et al., 2015).

The regression equation obtained from the statistical analysis of SCOD data is as follows

$$
\begin{array}{ll} 
& \mathrm{SCOD}(\mathrm{mg} / \mathrm{L})=8281-130 T-293 t+78 D \\
& +547 T t+206 T D+19 t D \\
3 . & +529 T^{2}+223 t^{2}+29 D^{2}
\end{array}
$$

A correlation coefficient of $75 \%$ was observed. RF temperature and holding time were found to have a negative effect on SCOD release. This may be due to the fact that the SCOD could be further oxidised and/or decomposed into carbon dioxide $\left(\mathrm{CO}_{2}\right)$ at a higher temperature and a longer reaction time, therefore, the concentrations for trials 4 and 8 did not increase as much as that of trial 13. The combined effect of temperature and time and temperature and dosage were also found to be an important factor for SCOD release. $\mathrm{H}_{2} \mathrm{O}_{2}$ dosage had a positive effect on SCOD release, indicating an increase in dosage would result in higher SCOD concentration in the treated solution. Similarly, the interaction effect of temperature and dosage had relatively larger positive effect on SCOD release. When lower dosage of $\mathrm{H}_{2} \mathrm{O}_{2}$, which was not sufficient to react with manure particles, was used, second order of $\mathrm{H}_{2} \mathrm{O}_{2}$ dosage as well as second order of power intensity had positive effects on SCOD release, and the effect of $\mathrm{H}_{2} \mathrm{O}_{2}$ dosage itself became negative on solids disintegration (Nkansah-Boadu et al., 2015). The results from these two studies demonstrated that the degree of solids disintegration was determined by a combination of $\mathrm{H}_{2} \mathrm{O}_{2}$, temperature and reaction time in $\mathrm{RF} / \mathrm{H}_{2} \mathrm{O}_{2}$; however, each factor had a different impact on SCOD release. The surface response profile of three factors on SCOD release in this study is shown in Figure 2. The optimal operating condition for releasing SCOD was at a temperature of $83^{\circ} \mathrm{C}$, holding time of $60 \mathrm{~min}$ and $\mathrm{H}_{2} \mathrm{O}_{2}$ dose of $1.7 \%$.

VFA concentration of the raw manure was $0.9 \mathrm{~g} / \mathrm{L}$ and increased to $5 \cdot 5 \mathrm{~g} / \mathrm{L}$ after $\mathrm{RF} / \mathrm{H}_{2} \mathrm{O}_{2}$ treatment, a remarkable increase from the initial value. The VFA was present mainly in the form of acetic acid; however, other VFAs such as propionic, butyric and valeric were also found along with acetic acid after the RF treatment. The regression equation obtained from the statistical analysis of VFA data is as follows

$$
\begin{aligned}
& \quad \text { VFA }(\mathrm{g} / \mathrm{L})=5+0 \cdot 18 T-0 \cdot 03 t+0 \cdot 13 D \\
& +0 \cdot 05 T t+0 \cdot 3 T D+0 \cdot 1 t D 0 \cdot 1 T^{2} \\
& \quad+0.05 t^{2}+0.35 D^{2}
\end{aligned}
$$

A correlation coefficient of $66 \%$ was observed. The optimised operating conditions for releasing VFA into solution were a 
Effect of hydrogen peroxide on

radiofrequency-oxidation of dairy manure

Srinivasan, Young, Liao and Lo
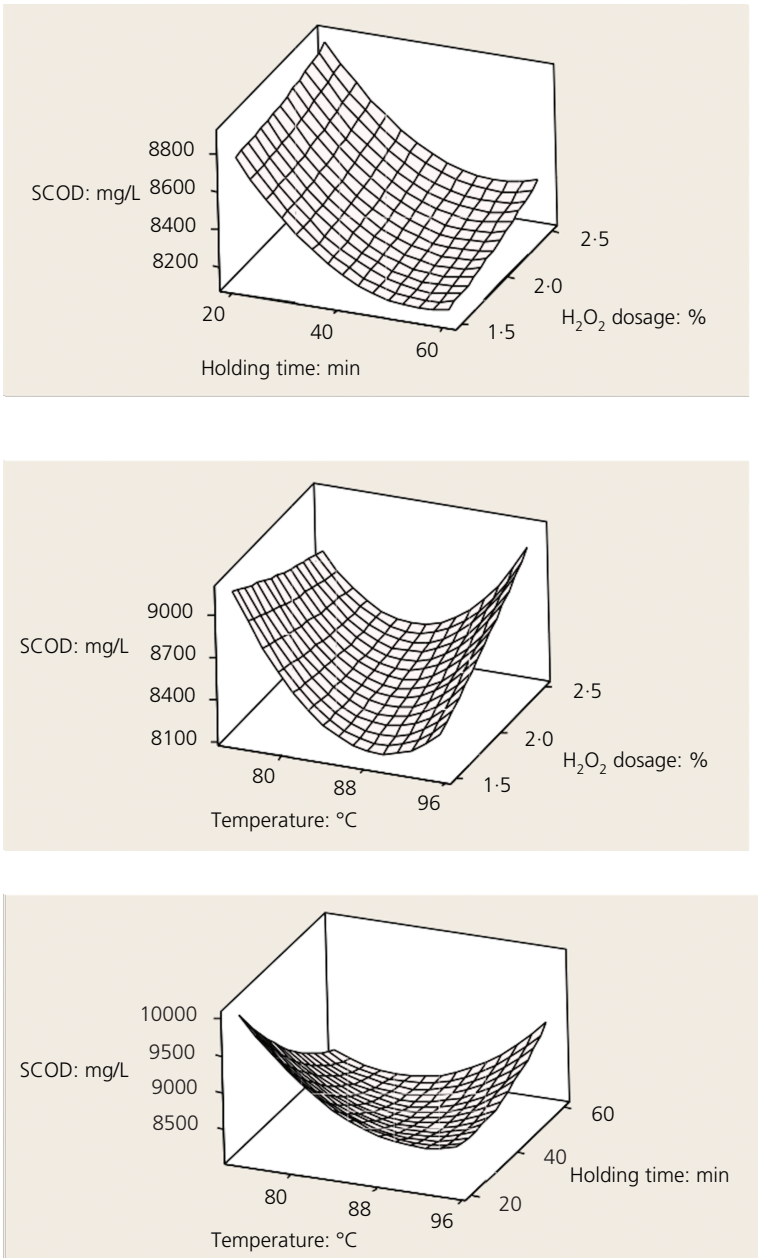

Figure 2. Surface plots for SCOD release

temperature of $89^{\circ} \mathrm{C}$, holding time of $49 \mathrm{~min}$ and $\mathrm{H}_{2} \mathrm{O}_{2}$ dose of $1 \cdot 8 \%$. VFA concentrations were found to increase with increasing temperatures and dosage. Lowest VFA concentrations were obtained at $75^{\circ} \mathrm{C}$ (trials 9,12 and 13). In $\mathrm{RF} / \mathrm{H}_{2} \mathrm{O}_{2}$ treatment of dairy manure, organic matters could be transformed to VFA at high temperatures via thermal decomposition and oxidation: $\mathrm{H}_{2} \mathrm{O}_{2}$ would also facilitate oxidation in $\mathrm{RF} / \mathrm{H}_{2} \mathrm{O}_{2}$. A higher dosage favours a higher VFA production. The VFA concentration was almost twice as high as those observed by Nkansah-Boadu et al. (2015). Higher levels of VFA would help in subsequent anaerobic digestion of $\mathrm{RF} / \mathrm{H}_{2} \mathrm{O}_{2}$-treated manure. However, an increase in holding time was found to result in lower VFAs. The decrease in VFAs with a longer reaction time could be due to either vaporisation of VFAs or oxidation to $\mathrm{CO}_{2}$ generation as the end product.

\section{Energy estimation and potential benefits}

The energy required for the $\mathrm{RF} / \mathrm{H}_{2} \mathrm{O}_{2}$ process was estimated using the method of Danesh et al. (2008). The energy required by the $\mathrm{RF} / \mathrm{H}_{2} \mathrm{O}_{2}$ batch system for separated manure was in a range of
191-291 kJ/L. The energy required for $\mathrm{RF} / \mathrm{H}_{2} \mathrm{O}_{2}$ heating of manure was comparable to that of previous $\mathrm{RF} / \mathrm{H}_{2} \mathrm{O}_{2}$ and $\mathrm{MW} / \mathrm{H}_{2} \mathrm{O}_{2}$-AOP processes (Nkansah-Boadu et al., 2015).

The $\mathrm{RF} / \mathrm{H}_{2} \mathrm{O}_{2}$ process would result in reducing solids content and improving settleability, as well as releasing phosphorus and magnesium into solution. Phosphorus removal and recovery by struvite crystallisation (magnesium ammonium phosphate) from dairy wastewater would also improve the effluent quality. The high SCOD concentration in the $\mathrm{RF} / \mathrm{H}_{2} \mathrm{O}_{2}$-treated solution would help in an anaerobic digestion process. Overall, the $\mathrm{RF} / \mathrm{H}_{2} \mathrm{O}_{2}$ treatment of dairy manure may improve nutrient management efficiency, environmental performance and potential for new revenue streams resulting from biogas production and struvite sales for the dairy industry.

\section{Conclusions}

The results indicated that the optimal operations for both SCOD and ortho-P yield were predicted to be RF temperature of $83^{\circ} \mathrm{C}$, holding time of $55-60 \mathrm{~min}$ and $\mathrm{H}_{2} \mathrm{O}_{2}$ dose of $1 \cdot 7-1 \cdot 8 \%$. The $\mathrm{RF} / \mathrm{H}_{2} \mathrm{O}_{2}$ process was as effective as $\mathrm{MW} / \mathrm{H}_{2} \mathrm{O}_{2}-\mathrm{AOP}$ for the treatment of dairy manure; both processes provided similar treatment efficiency in terms of solids disintegration, release of nutrient and metals.

\section{Acknowledgements}

Research funding from the Natural Science and Engineering Research Council (NSERC) of Canada is acknowledged. In addition, technical assistance provided by Tim Ma and Paula Parkinson is recognised.

\section{REFERENCES}

APHA (1998) Standard Methods for the Examination of Water and Wastewater, 20th edn. Am. Public Health Association, Washington, D.C., USA.

Barnett G (1994) Phosphorus forms in animal manure. Bioresource Technology 4(2): 139-147.

Chan WI, Liao PH and Lo KV (2010) Effects of irradiation intensity and $\mathrm{pH}$ on nutrients release and solids destruction of waste activated sludge using the microwave enhanced advanced oxidation process. Water Environment Research 82(11): 2229-2238.

Danesh P, Hong SM, Moon KW and Park JK (2008) Phosphorus and heavy metal extraction from wastewater treatment plant sludge using microwaves for generation of exceptional quality biosolids. Water Environmental Federation 80(9): 784-795.

Hjorth M, Christensen KV, Christensen ML and Sommer SG (2010) Solid-liquid separation of animal slurry in theory and practice: a review. Agronomy for Sustainable Development 30(1): 153-180.

Jin Y, Hu Z and Wen Z (2009) Enhancing anaerobic digestibility and phosphorus recovery of dairy manure through microwave-based thermochemical pretreatment. Water Research 43(14): 3493-3502. 
Journal of Environmental Engineering and

Science

Volume 10 Issue JS2
Effect of hydrogen peroxide on

radiofrequency-oxidation of dairy manure

Srinivasan, Young, Liao and Lo
Kenge AA, Liao PH and Lo KV (2009) Treating solid dairy manure using microwave-enhanced advanced oxidation process. Journal of Environmental Science and Health Part B 44(6): 606-612.

Lagunas-Solar MC, Cullor JS, Zeng NX et al. (2005) Disinfection of dairy and animal farm wastewater with radiofrequency power. Journal of Dairy Science 88(11): 4120-4131.

Laughton MA and Warne DF (2003) Electrical Engineers Reference Book, 16th edn. George Newnes, Burlington, MA, USA, pp. 9-21.

Lo KV and Liao PH (2011) Microwave enhanced advanced oxidation process application to treatment of dairy manure. In Microwave Heating (Chandra U (ed.)). In Tech, Rijeka, Croatia. Minitab (2007) Meet Minitab 15 for Windows. Minitab Inc., State College, PA, USA.

Nkansah-Boadu F, Srinivasan A, Liao PH and Lo KV (2015) Radiofrequency oxidation treatment of separated dairy manure. Process Biochemistry, http://dx.doi.org/10.1016/j. procbio.2015.05.020.
Pan SH, Lo KV, Liao PH and Schreier H (2006) Microwave pretreatment for enhancement of phosphorus release from dairy manure. Journal of Environmental Science and Health Part B 41(4): 451-458.

Ramaswamy $\mathrm{H}$ and Tang J (2008) Microwave and radio frequency heating. Food Science and Technology International 14(5): 423-427.

Rico JL, Garcia H, Rico C and Tejero I (2007) Characterisation of solid and liquid fractions of dairy manure with regard to their component distribution and methane production. Bioresource Technology 98(5): 971-979.

Wolf AM, Kleinman PA, Sharpley AN and Beegle DB (2005) Development of a water-extractable phosphorus test for manure: an interlaboratory study. Soil Science Society of America 69(3): 695-700.

Zhang H, Lo KV, Thompson JR et al. (2015) Recovery of phosphorus from dairy manure: a pilot-scale study. Environmental Technology 36(11): 1398-1404.

\section{WHAT DO YOU THINK?}

To discuss this paper, please submit up to 500 words to the editor at journals@ice.org.uk. Your contribution will be forwarded to the author(s) for a reply and, if considered appropriate by the editorial panel, will be published as a discussion in a future issue of the journal. 